\title{
Mirar el mundo a la luz de la Trinidad Reflexiones sobre la dimensión trinitaria de la teología
}

\author{
Look at the World in the Light of the Trinity \\ Reflections on the Trinitarian Dimension of Theology
}

\author{
Domingo García Guillén \\ Seminario Diocesano de Alicante \\ Alicante, España \\ ddomingog@gmail.com \\ ID ORCID 0000-0002-9279-2943
}

\begin{abstract}
Resumen: El misterio de la Trinidad constituye el centro de la fe cristiana. Para la teología es también la verdad fundamental, que ilumina las demás realidades creídas. Esta situación indica que ha quedado atrás el "esplendido aislamiento" de la doctrina trinitaria que denunciaban los grandes teólogos del siglo XX. El presente trabajo pretende mostrar los logros de esta renovación trinitaria de la teología, especialmente en los ámbitos de la antropología teológica, la teología de la familia, la eclesiología y la doctrina social de la Iglesia. Junto con los frutos maduros de esta nueva dimensión trinitaria de la teología, no se ocultan sus límites y riesgos. Creemos que esta nueva proposición trinitaria de las verdades cristianas puede ser válida en nuestro contexto postmoderno y postsecular.
\end{abstract}

Palabras claves: Ecclesia de Trinitate, Imagen de Dios, comunión, eclesiología

\begin{abstract}
The Mystery of the Trinity is the center of Christian faith. For theology, it is also the fundamental truth, which enlightens the other believed realities. This situation indicates that the "splendid isolation" of the Trinitarian doctrine denounced by the great theologians of the 20th century has been left behind. This paper aims to show the achievements of this Trinitarian renewal of theology, especially in the fields of theological anthropology, the theology of the family, ecclesiology and the social doctrine of the Church. Along with the ripe fruits of this new dimension of Trinitarian theology, its limits and risks are not hidden. We believe that this new Trinitarian proposal of Christian truths may be valid in our post-modern and post-secular context.
\end{abstract}

Palabras claves: Ecclesia de Trinitate, Image of God, Communion, ecclesiology 


\section{EL DISCURSO PÚBLICO SOBRE DIOS: ENTRE EL EXCESO Y LA IRRELEVANCIA}

La obra de ficción de Umberto Eco (1932-2016) se beneficia de la inmensa cultura del autor y sus importantes estudios en el ámbito de la estética y la semiótica. Baudolino (2000) es una original novela picaresca ambientada en el siglo XII. ${ }^{1}$ El personaje que da nombre a la obra entra en contacto con algunos de los grandes personajes de su tiempo, como el emperador Federico II Barbarroja al que sirve, y el historiador bizantino Nicetas Coniates, que recibe el relato de sus peripecias y mistificaciones. Asistimos también a hechos históricos como el nacimiento de la ciudad piamontesa de Alessandria, patria del protagonista y del propio Eco. Junto con la historia"documentable", el relato refleja un conocimiento exhaustivo de los relatos míticos de viajes y los bestiarios de animales fantásticos que nos han llegado de la Edad Media.

En uno de los capítulos más logrados, Baudolino y sus compañeros llegan a Pndapetzim, a las puertas del reino mítico del Preste Juan, situado idealmente en el Lejano Oriente. Allí se encuentran con esciápodos, blemias, pigmeos... y otras singulares criaturas. El esciápodo, que les sirve de guía y anfitrión, está dotado de un único y enorme pie que le sirve para darse sombra (de ahí su nombre). En vano tratan los viajeros occidentales de convencer a esta criatura para que reconozca ante ellos la singularidad de su forma corporal. Las únicas diferencias que reconoce respecto del resto de las criaturas que pueblan el reino son de naturaleza teológica. Cada raza profesa una variante exótica de las herejías trinitarias de la antigüedad, juzgando como heréticas al resto de criaturas, que "piensan mal" de Cristo y la Trinidad.

La extraordinaria diversidad teológica y morfológica de las criaturas suscita distintas interpretaciones a lo largo de la novela. Baudolino y sus compañeros dan máxima importancia a la diversidad física de las criaturas, mientras tienden a ignorar sus diferencias teológicas, que les parecen superfluas. ${ }^{2}$ Para el eunuco Práxeas, cada criatura reconoce la monstruosidad de sus vecinos pero ignora

\footnotetext{
1 Cf. Umberto Eco, Baudolino, Milano, Bompiani, 2000. Seguimos la preciosa traducción de Helena Lozano Miralles: Barcelona, Lumen, 2001.

2 Cf. Eco, Baudolino, 371-372.
} 
la propia. ${ }^{3}$ Por fin, el diácono Juan, hijo del mítico Preste, considera que mientras las divergencias de las distintas razas se ciñan al ámbito teológico podrá haber paz en aquel reino. Al fin y al cabo - razona- “ ¿qué importa saber cómo es de verdad la Santísima Trinidad? Basta con que esta gente siga los preceptos del Evangelio, y no irán al Infierno únicamente porque piensan que el Espíritu procede solo del Padre". ${ }^{4}$

Cuando se cierran las páginas de Baudolino, se advierte que es más que una obra de ficción. Sus líneas están sostenidas por una densa obra teórica. Llamarla"novela histórica" es correcto con tal que entendamos bien de qué tipo de historia se trata. El semiólogo Eco había propuesto años atrás "diez modos de soñar la Edad Media". ${ }^{5}$ Esta novela sería la undécima, destinada a interpelar nuestro presente. ${ }^{6}$ El Medievo de Baudolino tiene mucha historia delante y detrás de sí. La unidad de las razas a las puertas del imaginario reino del Preste Juan contrasta con la muy real y documentada división de los cristianos, que favoreció la caída de Bizancio en 1453. ${ }^{7}$ El modo en que el diácono contempla las diferencias doctrinales de las distintas razas está teñido de esa "tolerancia" que nació como hija natural de las guerras de religión de la Edad Moderna. De ella nacería a su vez una religión confinada en los límites de la razón estricta. ${ }^{8}$

Recuerdo haber leído esta novela poco antes de iniciar mi especialización en teología trinitaria. Su curiosa lectura de las herejías cristianas, a las que meses después tendría que dedicar tanto tiempo, se me quedó grabada en la memoria. Las aventuras de Baudolino y sus compañeros en Pndapetzim primero me hicieron reír y después me han dado mucho que pensar. Creo que Eco pretendía las dos cosas. Soy consciente de que no hay que tomar sus novelas demasiado

\footnotetext{
3 Cf. Eco, Baudolino, 386.
}

4 Eco, Baudolino, 405.

5 Cf. Umberto Eco, De los espejos y otros ensayos, Barcelona, Lumen, 1988, 84-96 ("Diez modos de soñar la Edad Media").

6 Cf. Guillermo Antonio Coll FerRARI, Modelos medievales y reescrituras posmodernas: Lectura crítica de "Baudolino", Madrid, Tesis UCM, 2019: <https://eprints.ucm. es/id/eprint/51563/> [Consulta: 31 mar. 2021]. También Gonzalo Soto PosAdA, Filosofía Medieval, Bogotá, San Pablo, 2007, 181-240.

7 Pienso la caída de Bizancio en los vivos colores pintados por Stefan ZwEIG, Momentos estelares de la humanidad, Barcelona, Acantilado, 2002, 37-66.

8 Cf. Immanuel Kant, La Religión dentro de los límites de la mera Razón, Madrid, Alianza, ${ }^{3} 2016$. 
al pie de la letra. La semiótica — según la teoría del propio Eco— trata de explicar la mentira. ${ }^{9}$ De hecho, en otra de sus obras, lo que parecía ser el protocolo de una sociedad secreta acaba por ser una simple lista de lavandería. ${ }^{10}$ Aún así, siempre me ha parecido que esta historia admite una lectura teológica, que me permitiré intentar.

Quienes han recibido el encargo de hablar sobre Dios en ámbito académico recuerdan a veces al esciápodo descrito por Umberto Eco. Yo mismo, cuando he tratado de explicar a qué dedicaba tantas horas de estudio, he visto asomar en los ojos de quienes me preguntaban, primero la sorpresa, después la perplejidad, finalmente la compasión. Comprendo que, a ojos de algunos observadores, los teólogos parezcan criaturas extrañas. Hablamos una lengua a menudo incomprensible. Pasamos tanto tiempo con los de nuestra "raza", damos tantas vueltas sobre nuestros temas, que acabamos naturalizando nuestras propias rarezas. Eco nos conocía bien, y como en toda caricatura, captó algunos rasgos verdaderos, deformando otros. La historia de la curiosa criatura invita a los teólogos a no aislarse en sus discusiones y concebir su actividad como un servicio. El único pie del esciápodo debería dar sombra también a otros.

Pero la lectura teológica tiene que seguir. La cuestión no es solo cómo es el esciápodo, sino cómo lo perciben los demás. Hay varias opiniones sobre la curiosa criatura y sus opiniones trinitarias. Cada mirada, en función de sus propios intereses, deforma como "monstruo" a los otros. ${ }^{11}$ El diácono sostiene un dulce pluralismo relativista: en el reino que aparentemente gobierna, cada cual puede sostener la opinión que quiera, mientras se mantenga la convivencia. Más que pluralismo, hay un cierto politeísmo político. ${ }^{12}$ En el extremo contrario se sitúa el eunuco Práxeas, que toma su nombre del hereje patripasiano del siglo tercero: para él, la diferencia trinitaria es mera apariencia, como lo es el gobierno del diácono. Solo hay un Dios en

9 Cf. Umberto Eco, Tratado de semiótica general, Barcelona, Lumen, 52000, 21-22.

10 Cf. Umberto Eco, El péndulo de Foucault, Madrid, Círculo de Lectores, 1990, 485-488.

11 Cf. Cristina Farronato, "Umberto Eco's Baudolino and the language of monsters", Semiotica 144 (2003) 319-342: <DOI:10.1515/semi.2003.029>. [Consulta: 31 mar. 2021].

12 Cf. Odo Marquard, Adiós a los principios. Estudios filosóficos, Valencia, Alfons el Magnànim, 2000, 99-123 ("Elogio del politeísmo. Sobre monomiticidad y polimiticidad"). 
el cielo, y una autoridad (la suya) en la tierra. Baudolino y sus compañeros, como buenos caballeros latinos, están más preocupados por cuestiones eminentemente prácticas, como la legitimidad del poder papal. No pueden dejar de sonreírse ante esas extrañas criaturas que son los teólogos, por esas discusiones que les parecen "cuestiones bizantinas".$^{13}$

El eunuco, el diácono y los caballeros latinos, a pesar de las diferencias de su mirada, incorporan un elemento común de extrañeza. Todos se sorprenden de la franqueza y naturalidad con la que el esciápodo trata cuestiones trinitarias tan difíciles. Y hay que reconocer que, en cierto sentido, la tradición teológica les da la razón. El misterio santo de Dios no puede convertirse en divertimento de aficionados a la retórica, reducido a objeto de conversaciones chabacanas, maltratado en discusiones banales. Umberto Eco podría haberse inspirado en la amplia difusión popular que tuvo la herejía de Eunomio en el siglo cuarto. Así la describe Gregorio de Nisa: "Si pides que te devuelvan el cambio, uno filosofa contigo sobre acerca del Engendrado o del Ingénito. Si preguntas cuánto vale el pan, aquél te responde: El Padre es mayor y el Hijo inferior. Si tú dices: ¿el baño está preparado?, aquel define que el Hijo es de la nada".$^{14}$

Difícilmente podríamos negar el riesgo de maltratar el misterio santo de Dios con vacías discusiones de palabras. Pero tampoco se puede condenar a la irrelevancia el discurso público sobre Dios y su misterio trinitario. Un teólogo descuidaría su encargo eclesial y su responsabilidad académica si decidiera confinarse a los espacios eclesiales, renunciando a aportar su voz a la polifonía de las voces del debate contemporáneo.

Se trata, en primer lugar, de poder hablar públicamente de Dios. El Juan de Mairena de Antonio Machado se excusaba al explicar el argumento ontológico de san Anselmo. "Y digo perdonad porque, en nuestro tiempo, se puede hablar de la esencia del queso manchego, pero nunca de Dios, sin que se nos tache de pedantes".${ }^{15}$ Cada

\footnotetext{
13 "Me parece una cosa de grecanos. Nosotros en el norte estábamos más preocupados por quién era el papa verdadero y quién el antipapa": Eco, Baudolino, 372.

14 Gregorio de Nisa, De deitate Filii et Spiritus Sancti et in Abraham (Gregorii Nysseni Opera X/2,120-121). Me he ocupado anteriormente de esta cuestión, cf. Domingo García Guillén, "Padre es nombre de Relación". Dios Padre en la Teología de Gregorio Nacianceno (AnGr 308), Roma, Gregorian \& Biblical Press, 2010, 43-49.

15 Antonio Machado, Obras. Poesía y prosa, vol. I, Buenos Aires, Losada, 1997, 475.
} 
generación necesita escuchar el nombre de Dios. Y escucharlo en el espacio público común, donde los hombres y mujeres intercambian sus ideas, hacen la vida y crean ámbitos de convivencia común. ${ }^{16}$ También nuestra sociedad, que encuentra tantas dificultades para definirse y tiene que situarse como posterior a otras épocas históricas: post-ilustrada, post-moderna, post-secular... Con todas sus ambigüedades y deficiencias, nuestro tiempo tiene hambre y sed de una palabra adecuada sobre Dios. ${ }^{17}$

En este discurso público sobre Dios no puede faltar la teología. Hay que reclamar su lugar como ciencia específica del discurso sobre Dios, como Palabra divina acogida humildemente en la fe, pensada desde una razón creyente, en solidaridad con las otras ciencias y expuesta al riesgo de la comunicación. ${ }^{18}$ Una fe hecha cultura y pensamiento, capaz de dialogar con otras visiones del hombre y de la historia, que no se deja encerrar en los prejuicios, ni en los propios ni en los extraños.

Se trata de hablar de Dios, tal y como se nos ha revelado en Jesucristo. Misterio de comunión trinitaria, eterno amor del Padre, del Hijo y el Espíritu Santo, hecho historia en Jesús de Nazaret. Se trata de una luz que se reveló para hacerse pública, no para ocultarse de las miradas extrañas ni convertirse en objeto de cuchicheo de iniciados (Mt 5,16; 10,27). Los creyentes no pueden guardarse esta luz para sí mismos, si no quieren faltar al mandato de su Maestro. El mandato bautismal, que contiene una de las confesiones trinitarias más antiguas, insiste hasta cuatro veces en la totalidad del anuncio:

16 Cf. Santiago Del Cura Elena, "A tiempo y a destiempo. Elogio del Dios (in) tempestivo", Burgense 43 (2002) 323-378 (especialmente 355-360); Olegario González de Cardedal, Dios en la ciudad. Ciudadanía y cristianía (PDLD 86), Salamanca, Sígueme, 2013.

17 Cf. Carmelo Dotolo, Dio, sorpresa per la storia. Per una teologia post-secolare (BTCon 199), Brescia, Queriniana, 2020; Joâo Duque, El Dios ocultado. En busca de un diálogo crítico con la sociedad (VeIm 201), Salamanca, Sígueme, 2017; Emilio José Justo, Después de la modernidad. La cultura posmoderna en la perspectiva religiosa (CPrT 284), Maliaño, Sal Terrae, 2020.

18 Olegario GonzÁlez dE CARDEDAl ya reclamaba ese "lugar" en su ingreso como académico de las Ciencias Morales y Políticas: El lugar de la teología, Madrid, Real Academia de Ciencias Morales y Políticas, 1986. Después de él, cf. Mariano Álvarez Gómez, Pensamiento del ser y espera de Dios (Hermeneia, 57), Salamanca, Sígueme, 2004, 569-592; Ángel Cordovilla, En defensa de la teología. Una ciencia entre la razón y el exceso (VeIm 201), Salamanca, Sígueme, 2014, especialmente 35-53 ("Teología y sociedad"). 
Se me ha dado todo poder en el cielo y en la tierra. Id, pues, y haced discípulos a todos los pueblos, bautizándolos en el nombre del Padre y del Hijo y del Espíritu Santo; enseñándoles a guardar todo lo que os he mandado.Y sabed que yo estoy con vosotros todos los días, hasta el final de los tiempos (Mt 28,18-20).

\section{SALIR DEL AISLAMIENTO}

Esta centralidad del misterio trinitario en la vida de los cristianos apenas podrá discutirse en el plano teórico. Otra cosa es si esta verdad impregna la vida espiritual de los cristianos de a pie; si tiene un lugar en los distintos niveles de la catequesis y enseñanza cristiana; e incluso si en la reflexión teológica constituye el centro e inspiración del resto de misterios cristianos. Cualquiera que conozca un poco la historia teológica reciente reconoce el eco de los lamentos formulados por los grandes teólogos de la segunda mitad del siglo xx sobre la irrelevancia del misterio trinitario. ${ }^{19}$

El mérito, sin duda, es de Karl Rahner. Nadie supo expresar como él la situación que aquejaba al misterio trinitario en todos los contextos de la vida cristiana: la espiritualidad, la catequesis y también la teología. ${ }^{20}$ Sus expresiones, certeras e impactantes, quedaron en el imaginario teológico de toda una generación. En su crudeza y aparente inverosimilitud, las expresiones empleadas por Rahner descubrían una realidad sangrante que no podía seguir ignorándose:

Los cristianos, a pesar de su confesión ortodoxa de la Trinidad, son en la realización de su existencia religiosa casi exclusivamente "monoteístas". Podríamos atrevernos a afirmar que si hubiera que desechar, por falsa, la doctrina trinitaria, la mayor parte de la bibliografía religiosa podría permanecer casi tal y como está. ${ }^{21}$

Este era el síntoma de la enfermedad descrita por Rahner, que también ofrecía un tratamiento con su conocido (y criticado) axioma fundamental de la teología trinitaria. Pero lo más importante era el

19 Cf. Domingo García Guillén, “De la teología de la Trinidad a la teología trinitaria. La fecundidad de un camino de renovación", Estudios trinitarios 54 (2020) 269314, especialmente 273-292.

20 Cf. Karl RahneR, "Advertencias sobre el tratado dogmático «De Trinitate»", en Escritos de Teología vol. IV, Madrid, Taurus, 1964, 105-136.

21 RAHNER, "Advertencias sobre el tratado dogmático «De Trinitate»", 107. 
diagnóstico, la descripción precisa de la enfermedad: el misterio trinitario vivía en un "espléndido aislamiento". Nadie dudaba del valor del misterio central de la fe, pero apenas influía en la configuración de la vida cristiana, la enseñanza del catecismo o la propuesta teológica. Rahner cifraba este aislamiento en que la Trinidad se limitaba a ser un tratado teológico entre otros. "Después de haber sido despachado este tratado en la dogmática no vuelve a aparecer de nuevo". ${ }^{22}$

Hans Urs von Balthasar había expresado una queja similar unos años antes que Rahner. En su profético librito Abatir los Bastiones (1952), el suizo constataba el inmovilismo que reinaba en algunos ambientes teológicos:

Hay teólogos que parecen opinar que la teología (es decir, la interpretación de la Revelación en conceptos humanos) ha progresado tanto que está a punto de cerrarse. La casa les parece construida, la habitación tapizada. A las generaciones venideras les queda un trabajo más pequeño y sutil: la decoración de los espacios terminados, de los espacios intermedios que cada vez son menos, la distribución en cajones.Y al final solo queda limpiar el polvo. ${ }^{23}$

Frente a esta falsa seguridad, el joven Balthasar comparaba el estado de la investigación teológica con la febril actividad geográfica y exploradora de los siglos anteriores. A diferencia de aquella, a la teología le quedaban continentes enteros por explorar. Muchos huecos en el mapa todavía. La inacción y la pasividad no tenían excusa. Los desarrollos teológicos, incluyendo los avances trinitarios y cristológicos de los primeros siglos cristianos, no pasan de ser esbozos, balbuceos... Queda mucho por hacer, como se observa si miramos la situación de la Trinidad en la vida de los cristianos:

¿Cuál es el lugar de la doctrina de Dios uno y Trino en la existencia cristiana? ¿Y cuál tuvo en teología, donde esta doctrina parece haberse quedado detenida y como congelada desde la especulación psicológica de Agustín? Junto al magnífico camino de Agustín, podría haber muchos otros caminos, aún mejores quizá (al fin y al cabo, la estructura solitaria del alma no puede ser la imagen suprema del intercambio viviente de amor en el Dios eterno). ¿Por qué no se buscan y se siguen estos caminos? ¡Qué vivo podría ser el

22 RAHNER, "Advertencias sobre el tratado dogmático «De Trinitate»", 110.

23 Hans Urs von Balthasar, Schleifung der Bastionen. Von der Kirche in dieser Zeit, Trier, Johannes, ${ }^{5} 1989,16-17$. Las traducciones son mías. 
anuncio cristiano en la escuela, en el púlpito, en las cátedras, si todos los tratados teológicos estuvieran configurados de forma trinitaria! ${ }^{24}$

El aislamiento que Rahner formulaba en negativo tiene en Hans Urs von Balthasar una forma propositiva: habría que configurar trinitariamente todos los tratados teológicos. La renovación teológica habría de pasar, necesariamente, por la superación del aislamiento y la renovación trinitaria de la teología. Y así sucedió. Pero las cosas fueron un poco distintas de lo que suponían los dos maestros del pasado siglo.

El Concilio Vaticano II (1962-1965) favoreció la renovación de numerosos tratados teológicos. Comenzó la eclesiología, alentada por la espectacular atención que había recibido la Iglesia en los documentos del Concilio. Entrando en la década de los setenta, fue la cristología la que centró los esfuerzos de los teólogos. Por fin, en los años ochenta comenzó a elaborarse una nueva teología trinitaria. La secuencia Iglesia-Cristo-Trinidad indica la lógica de una profundización, cada vez mayor, en el misterio cristiano: ahondar en la eclesiología llevó a preocuparse por afianzar la base cristológica de la Iglesia; reflexionar sobre Jesucristo condujo a la pregunta por la profundidad trinitaria de su mensaje. ${ }^{25}$ No fue la teología trinitaria la que impulsó a los otros tratados, sino al revés. A principios de los años setenta lo había advertido Wilhelm Breuning:

Los verdaderos impulsos renovadores no se han producido [...] por el desarrollo inmanente a la doctrina trinitaria tradicional [...], sino más bien desde fuera. La imagen de una renovada doctrina trinitaria se dibujó sobre el fundamento de la renovación de la cristología, la antropología, la doctrina de la gracia, la eclesiología, o al menos cuando éstas se hallaban en proceso de renovación. ${ }^{26}$

24 Von Balthasar, Schleifung der Bastionen, 17-18.

25 Cf. Werner LÖSER, “Trinitätstheologie heute. Ansätze und Entwürfe”, en Wilhelm Breuning, (ed.), Trinität. Aktuelle Perspektiven der Theologie (QD 110), Freiburg Basel - Wien, Herder, 1984, 19-45 (aquí 20).

26 Wilhelm Breuning, "La Trinidad", en HerbertVorgrimler- Robert van Der Gucht, (ed.), La teología en el siglo XX vol. III (BAC.Ma 7), Madrid, Católica, 1974, 13-25 (aquí 14). 
El proceso, que Breuning describe como si ya se hubiera completado, estaba empezando en ese momento. ${ }^{27}$ Las necesidades expresadas por Rahner y Balthasar comenzarían a cumplirse a finales del pasado siglo, en la década de los noventa. Floreció entonces God for us. The Trinity and christian life [1993], de Catherine Mowry LaCugna. ${ }^{28}$ La teóloga norteamericana se esfuerza por evidenciar el carácter práctico de la doctrina trinitaria, mostrando su relevancia para distintos ámbitos como la eclesiología, la antropología teológica o la visión cristiana de la sexualidad. Junto con esta obra, hay que citar la propuesta de Gisbert Greshake: Der dreieine Gott. Eine trinitarische Theologie [1997]. ${ }^{29}$ No se trata de un libro más que hable del misterio de Dios como un capítulo especial de la teología, lo que denomina "teología de la Trinidad [Trinitätstheologie]". Su intención es ofrecer una perspectiva trinitaria de toda la realidad teológica y más allá de esta. A su proyecto le denomina"una teología trinitaria [trinitarische Theologie]". ${ }^{30}$ La luz del misterio trinitario de Dios se proyecta en las páginas del dogmático de Friburgo a tratados teológicos como la creación, la salvación, la eclesiología y la escatología.Y más allá del ámbito eclesial, la Trinidad ofrece una nueva comprensión del ser, la sociedad y el diálogo de las religiones.

Trabajos como los de LaCugna o Greshake indican que las propuestas de Rahner y Von Balthasar han comenzado a cumplirse en la teología contemporánea. La teología trinitaria ha salido de su"esplendido aislamiento"y ha comenzado a configurar el resto de tratados: puede hablarse de "inspiración" o"dimensión" trinitaria de toda

27 No hay un relato único del proceso reciente de renovación trinitaria. Tal vez sea pronto para escribirlo, aunque hay algunos intentos, cf. Marcelo GonZÁLEz, "El estado de situación de los estudios trinitarios en el umbral del Tercer milenio", en El Misterio de la Trinidad en la preparación del Gran Jubileo, Buenos Aires, San Pablo, 1998, 9-97; Giuseppe Marco SAlvatI, "Desarrollos de la teología trinitaria. De la Lumen Gentium a nuestros días", in Estudios Trinitarios 39 (2005) 3-22; Antonio Stagliano, "Teologia trinitaria", en Piero Coda - Giacomo Canobbio, La Teologia del XX secolo. Un Bilancio, vol. II, Roma, Città Nuova, 2003, 89-174.

Cf. Catherine Mowry LACugna, Dio per noi. La Trinità e la vita cristiana (BTCon 92), Brescia, Queriniana, 1997.

29 Cf. Gisbert GreshaKe, El Dios uno y Trino. Una teología de la Trinidad, Barcelona, Herder, 2001.

30 Cf. GreshaKe, El Dios uno y Trino, 43. Aquí la distinción está bien traducida. Sin embargo, no ocurre así en el subtítulo del libro: "eine trinitarische Theologie" se vierte al castellano como"una teología de la Trinidad". 
la teología, ${ }^{31}$ precisamente lo que Greshake llama una"teología trinitaria" frente a una "teología de la Trinidad" como tratado específico. Esto solo fue posible tras producirse la renovación en otros ámbitos como la eclesiología o la cristología.

La teología trinitaria ha conseguido salir del aislamiento tan solo cuando se ha dejado enriquecer por otros tratados para — a su vezproyectar luz sobre cada uno de ellos. El crecimiento de la teología trinitaria ha tenido que ver con su fecundidad. Vuelve a verificarse lo que Jesús dijo sobre su propia muerte y resurrección:"si el grano de trigo no cae en tierra y muere, se queda él solo; pero si muere, trae mucho fruto" (Jn 12,24).

Para constatar esta fecundidad trinitaria de la teología, examinaremos cuatro ámbitos en los que esta renovación se ha hecho más evidente: la antropología teológica, la teología de la familia, la eclesiología y la cuestión social.

\section{A IMAGEN DEL DIOS TRINITARIO}

La reflexión cristiana sobre el ser humano se beneficia, en primer lugar, de la visión trinitaria de la creación. Precisamente porque el creador es trinitario, porque en su seno existe la alteridad, podemos afirmar que la creación es libre y amorosa. Dios no necesita de las criaturas, pero desea compartir su bondad con ellas. La libertad amorosa de Dios es capaz de crear seres libres que pueden corresponderle en el amor. ${ }^{32}$

Desde la renovación trinitaria de la teología, cada vez es más común hablar de una"antropología trinitaria". Se trata de una expresión habitual en la literatura teológica, aunque los contenidos antropológicos varían notablemente de una propuesta a otra. ${ }^{33}$

31 Cf. Sergio Paolo Bonanni - Dariusz KowalczyK (eds.), La Trinità in dialogo. La dimensione trinitaria della teologia (Theologia 18), Roma, Gregorian \& Biblical Press, 2020.

32 Cf. Santiago del CuRA ElenA, " «Creación ex nihilo» como «creación ex amore». $\mathrm{Su}$ arraigo y consistencia en el misterio trinitario de Dios", Estudios trinitarios 39 (2004) 55-130; IDEM, "Personas en comunión. Elementos de antropología Cristiana en perspectiva trinitaria", en Congresso Internacional Santíssima Trindade Pai, Filho, Espirito Santo..., Fátima 2008, 699-738.

33 Cf. Antonio Bergamo, Identità reciprocanti. Figure e ritmica di antropologia trinitaria (CoTe.R 35), Roma, Città Nuova, 2016; Tiziana LonghiTANo, Il Dio uni-trino e l'unità plurale del genere umano. Considerazioni di antropologia trinitaria, Roma, 
A fin de hacer explícita la referencia trinitaria de la antropología, puede ser de gran ayuda la categoría bíblica "imagen de Dios". El primer requisito es recordar quién es ese Dios del que el hombre y la mujer son imagen: el Dios uno y trino. ${ }^{34}$

Pero, ¿en qué consiste esta imagen y en qué parte del ser humano reside? Desde la antigüedad cristiana, son varias las respuestas a esta pregunta. En 1 Tes 5,23, san Pablo describe al ser humano con tres elementos: cuerpo, alma y espíritu. De los tres, cada corriente teológica de la antigüedad destacó uno. Los gnósticos situaban la imagen en el espíritu. Los cristianos de raíz platónica (como Orígenes) dicen que la imagen está en el alma. Por fin, los autores que trataron de mantener la raíz semítica de la antropología bíblica (como Ireneo de Lyon), sostienen que el entero ser humano - cuerpo, alma y espíritu- es imagen de Dios. ${ }^{35}$ Históricamente, podría decirse que triunfó una visión mitigada de la antropología alejandrina que, eliminando los excesos de Orígenes, coincide con él en situar la imagen de Dios en el alma humana, apartándola del cuerpo. El ejemplo más clásico es Agustín de Hipona, aunque Tomás de Aquino elaboró también una reflexión de extraordinaria riqueza. ${ }^{36}$

El Hiponense encuentra la Trinidad en la tríada de facultades del alma: "mente, amor y conocimiento" o de "memoria, inteligencia y voluntad".$^{37}$ El Dios Trinitario nos creó a su imagen y semejanza, haciéndonos participar de su Sabiduría y su Amor. Por eso, cuando miramos nuestro interior tenemos conocimiento de la Trinidad. Y es que el hombre no es una criatura más. El ser humano no tiene solo "vestigios de la Trinidad", sino la "imagen de Dios", que le permite

Urbaniana University Press, 2021; Etienne VetÖ, "Rischi e chance di una antropologia teologica trinitaria", en BONANNI - KOWALCZYK (eds.), La Trinità in dialogo, 139-149.

34 Cf. Thomas A. Smail, "In the Image of the Triune God", International Journal of Systematic Theology 5 (2003) 22-32: <DOI: 10.1111/1463-1652.00092>; Kallistos WARE, "The Human Person as an Icon of the Trinity", Sobornost 8 (1986) 6-23: $<$ http://trinityinyou.com/pdfs/the_Human_Person_as_an_Icon_of_the_Trinity. pdf> [Consulta: 31 mar. 2021].

35 Cf. Antonio Orbe, Antropología de san Ireneo (BAC 286), Madrid, Católica, 1969, 527-531.

36 Cf. Olegario GonzÁLEZ de CARDEDAL, Teología y Antropología. El hombre "imagen de Dios" en el pensamiento de Santo Tomás, Madrid, Moneda y Crédito, 1967.

37 Cf. san Agustín de Hipona, De Trinitate IX 5,8 (CChr.SL 50,300); X 11,18 (CChr.SL 50,330). 
conocer a Dios a través de Dios. El ascenso desde el hombre hasta Dios descansa sobre el presupuesto de que Dios se ha quedado reflejado en su criatura al crearla. ${ }^{38}$

Admirando la síntesis agustiniana, podemos comprender la crítica que leíamos en Von Balthasar: "la estructura solitaria del alma no puede ser la imagen suprema del intercambio viviente de amor en el Dios eterno". ${ }^{39} \mathrm{El}$ autor suizo mantuvo estas reservas hasta el final de su vida. Así leemos en uno de sus últimos escritos: "el yo, con sus tres funciones es, en última instancia, solo un pálido reflejo, esencialmente deficiente, de la vida divina trinitaria". ${ }^{40}$ La teología trinitaria no puede limitarse a esta débil analogía con el hombre, que ignora incluso la capacidad relacional del hombre. Para algunos, la imagen de la Trinidad en el ser humano consiste precisamente en esta relacionalidad:

El Dios Uno y Trino ha revelado su proyecto de compartir la comunión de la vida trinitaria con personas creadas a su imagen. Es más, para esta comunión trinitaria las personas han sido creadas a imagen de Dios. Precisamente la posibilidad de una comunión de seres creados con las Personas increadas de la Santísima Trinidad se apoya en esta semejanza radical con el Dios Uno y Trino. ${ }^{41}$

El hombre es relacional a imagen de la Trinidad divina, donde cada persona es su relación. Pero no parece suficiente explicar la imagen divina en el ser humano como una relacionalidad genérica, sin más explicaciones. El ser humano tiene una relación con cada una de las personas divinas: con el Padre, el Hijo y el Espíritu Santo. ${ }^{42}$ De estas relaciones con cada persona divina, la fundamental es la que une al ser humano con el Hijo de Dios. Entre cristología y

38 Cf. Luigi GiorA, “La connaissance du Dieu Trinité chez saint Augustin. Par delà les embarras de l'analogie et de l'anagogie" en Emmanuel DurAND - Vincent HoLzer (éds.), Les sources du renouveau de la théologie trinitaire au XXe siècle (CFi 266), Paris, Cerf, 2008, 97-139.

39 Von Balthasar, Schleifung der Bastionen, 17-18.

40 Hans Urs von Balthasar, Teológica vol. II: Verdad de Dios, Madrid, Encuentro, 1997, 43.

41 Comisión Teológica Internacional, Comunión y servicio. La persona humana creada a imagen de Dios (2004) n. 25: <https://www.vatican.va/roman_curia/congregations/cfaith/cti_documents/rc_con_cfaith_doc_20040723_communion-stewardship_sp.html> [Consulta: 1 abril 2021].

42 Cf.VETÖ, "Rischi e chance di una antropologia teologica trinitaria", 153-154. 
antropología teológica hay un vínculo irrenunciable que la teología contemporánea ha subrayado con vigor ${ }^{43}$ Las principales categorías que conforman la antropología teológica tienen una profunda raíz cristológica: somos hijos en el Hijo, recibimos la vida divina que ha vivido el Hijo de Dios en la carne. También la teología de la imagen divina ha de interpretarse en relación con Jesucristo.

Hay una base bíblica para esta teología cristológica de la imagen. El libro del Génesis afirma tres veces que el ser humano fue creado a imagen de Dios (1,26-27; 5,1-3; 9,6). El segundo texto relaciona la imagen divina en el hombre con el aire de familia que une al padre y al hijo: "El día en que Dios creó al hombre, a imagen de Dios lo hizo [...] Adán tenía ciento treinta años cuando engendró un hijo a imagen suya, a su semejanza, y lo llamó Set" (5,1b-3). Este"a imagen" (betselem) se vierte al griego de los Lxx como kat'eikon ("según la imagen"). Filón de Alejandría distinguirá entre la Imagen misma y quien ha sido creado"según esta Imagen".${ }^{44}$ Cuando el Nuevo Testamento afirme que Cristo es "Imagen de Dios invisible" (Col 1,15) podrá decirse que el ser humano fue creado según esa Imagen, que es el Hijo de Dios.

Cada una de las tradiciones cristianas primitivas interpreta el "según la imagen" a su modo. Para Orígenes, el ser humano fue creado"según la Imagen" que es el Hijo eterno, sin referencia a la encarnación. La imagen de Dios reside, para el alejandrino, en el hombre interior. Si alguien pensara que el hombre corpóreo es imagen de Dios, estaría atribuyendo a Dios una forma corpórea y humana. ${ }^{45}$ Para otros padres de la Iglesia, la imagen divina alcanza también la carne del hombre. Sucede así con Justino, Ireneo de Lyon y algunos textos de Tertuliano. Este último invita a pensar en el momento de la creación del ser humano. El modelo que inspiró la creación del hombre no es otro que el Hijo de Dios que había de hacerse carne en Jesucristo.

43 Cf. Luis Francisco LadARIA, Introducción a la antropología teológica, Estella, Verbo Divino, 1993, 70-79 ("Cristología y antropología").

44 Cf. Orbe, Antropología de san Ireneo, 107-115.

45 Cf. Orígenes, Homilías sobre el Génesis I,13: ed. José Ramón Díaz Sánchez-Cid, Biblioteca de Patrística 48, Madrid, Ciudad Nueva, 1999, 90. 
Piensa en Dios totalmente ocupado en ello y absorbido con su mano, entendimiento, actividad, providencia y, sobre todo, con su cariño que le dictaba los rasgos. Cristo era el pensamiento de todo cuanto expresaba el limo, hombre futuro como el limo, y Palabra hecha carne, como entonces la tierra. Así habló el Padre al Hijo: hagamos al hombre a nuestra imagen y semejanza. E hizo al hombre Dios, es decir, lo que plasmó, a imagen de Dios lo hizo, es decir, a imagen de Cristo. ${ }^{46}$

El Concilio Vaticano II se apoyó en este texto de Tertuliano de Cartago para fundamentar su antropología teológica concebida en clave cristológica. ${ }^{47}$ Creo que hay muchas razones para recuperar en nuestros días esta antropología teológica desarrollada entre otros por Ireneo y Tertuliano (la denominada "tradición asiática"). Desde el punto de vista antropológico, tiene la ventaja de no dejar la carne del ser humano fuera del ámbito de la imagen divina. El ser humano concreto y completo ("cuerpo, alma y espíritu": 1 Tes 5,23) fue creado a imagen y semejanza de Dios. ${ }^{48}$ También tiene ventajas desde el punto de vista cristológico-trinitario. El Dios del que el hombre es imagen es sino el Hijo de Dios que se ha hecho carne en Jesucristo y nos ha insertado en su relación privilegiada con Dios Padre por medio del Espíritu Santo. Luis Ladaria, que ha elaborado su antropología teológica en la escuela de los padres, aplica a la filiación divina algo que podríamos entender de la imagen:

El punto inmediato de referencia para entender nuestra filiación divina no es el Hijo eterno en su vida intratrinitaria, sino el Hijo hecho carne, Jesús [...] No conocemos otro camino para que los hombres participemos en la vida divina más que la misión y encarnación del Hijo, enviado por el Padre para que pudiéramos recibir la adopción filial, y la misión del Espíritu del Hijo por el que podemos clamar"Abba Padre". ${ }^{49}$

46 Tertuliano, De resurrectione carnis V,8-VI,4 (CChL 2,927-928). Traducción de Roberto López Montero, Tertuliano y las manos de Dios. Un ensayo antropológico (Presencia y Diálogo, 33), Madrid, San Dámaso, 2012, 54.

47 Cf. Concilio Vaticano II, Constitución pastoral Gaudium et spes, n. 22, nota 20.

48 Cf. José Granados, "L'imago Dei nella carne: una proposta d'impostazione del rapporto antropologia-Trinità", en BONANNI - KowALCZYK (eds.), La Trinità in dialogo, 125-138.

49 Luis Francisco Ladaria, Teología del pecado original y de la gracia. Antropología teológica especial (SapFi 1), Madrid, BAC, 1993, 248. 
Años después de escribir este texto sobre antropología, Ladaria ha tenido ocasión de profundizar la visión trinitaria que se esboza en las líneas anteriores. No habla de Dios partiendo de la vida íntima de la Trinidad (lo que Karl Rahner denomina "Trinidad inmanente" y la patrística del siglo cuarto llama"theologia"). El discurso trinitario tiene que comenzar examinando atentamente la economía de la salvación. Ladaria entiende esta "economía" de un modo muy particular: "cómo el misterio de Dios se ha revelado en la vida de Jesús [...] desde su venida al mundo hasta su resurrección y exaltación a los cielos y la efusión del Espíritu Santo. Tratamos por tanto de exponer [...] una teología de los misterios de la vida de Cristo desde el punto de vista de la revelación del misterio de Dios ${ }^{\prime \prime 5}$. En la visión de Ladaria, que nosotros compartimos, una antropología inspirada trinitariamente se alimenta de la visión económico-salvífica de la Trinidad que proporciona la cristología de los misterios de la vida de Cristo en la carne.

Pero volvamos a la antropología. Hasta ahora hemos hablado de "hombre" y"ser humano" en términos genéricos. Sin embargo, el texto bíblico afirma "a imagen de Dios lo creó, varón y mujer lo creó" (Gen 1,26-27). La dimensión relacional de la imagen divina ha de aplicarse también a la diferencia sexual hombre-mujer. Aunque la realidad divina está más allá de la diferencia sexual, la comunión divina de las personas se ve reflejada en la irreductible diferencia hombre-mujer. ${ }^{51} \mathrm{Ni}$ el hombre ni la mujer por separado agotan la realidad divina de la imagen. Ambos sexos, en su mutua diferencia y relación, reflejan al Creador. Sin duda, hay que atribuir esta nueva perspectiva a la presencia de voces femeninas que son cada vez más audibles en teología..$^{52}$ Asimismo, hay que reconocer el impulso otorgado por san

50 Luis Francisco LaDARIA, El Dios vivo y verdadero. El misterio de la Trinidad (Ágape 19), Salamanca, Secretariado Trinitario, ${ }^{5} 2015,74$. Me he ocupado de este rasgo del pensamiento de Ladaria, cf. Domingo García Guillés, "Deus nescit aliud quam pater esse. Dios Padre en la teología de Luis F. Ladaria», Revista Española de Teología 80 (2020) 263-289 (aquí 269-272).

51 Sobre la exégesis de la "imago Dei", cf. Marc Ouellet, "Divina Somiglianza". Antropologia trinitaria della famiglia (SNTe 1), Roma, Lateran University Press, 2004, 41-50.

52 Cf. Angela Ales Bello, "L'antropologia duale come imago Dei", Teresianum 69 (2018) 391-410; Janet Martin Soskice, "Imago Dei y diferenciación sexual", Concilium no 314 (2006) 41-50; Blanca Castilla de Cortázar, "Mujer y teología. La cuestión de la imagen de Dios", Arbor 192/778 (2016): <DOI:10.3989/ arbor.2016.778n2005> [Consulta: 7 abr. 2021]. 
Juan Pablo II en Mulieris Dignitatem, que introduce dos significativas novedades: 1) establecer un puente entre la unidad dual hombremujer y las relaciones entre las personas divinas; 2) mostrar que la sexualidad forma parte de la imago Dei. ${ }^{53}$

Estas propuestas de fundamentación trinitaria de la sexualidad humana encuentran una audaz expresión en el concepto de sexualidad "católica" que defiende Catherine Mowry LaCugna, en estrecha dependencia de su concepto "católico" de persona. La teóloga norteamericana cifra la catolicidad de la persona humana en dos rasgos: su capacidad de abrazar todo lo que existe; y que cada persona humana expresa de modo único la naturaleza del hombre, sin que nadie pueda agotar la totalidad de la naturaleza. En esto se muestra su semejanza a las personas divinas, que ejemplifican de modo único la naturaleza divina. A imagen de Dios, donde cada persona existe en relación, en la salida de sí hacia el otro, la persona humana es"extática": se encuentra en salida hacia los otros. La condición sexuada de la persona manifiesta este rasgo extático: nos recuerda que estamos llamados al éxtasis, a la salida de nosotros mismos para unirnos a otra persona. Aunque la sexualidad trasciende el deseo sexual, en este se desmiente la ilusión de que la persona pueda existir para sí misma: aunque tiende a la exclusividad, ha de dejar paso a la inclusión. La sexualidad es "católica" e inclusiva cuando abre paso al otro. Así sucede tanto en el caso del hijo que nace de la relación conyugal, como del extraño al que se acoge. Quizá sorprenda ver esta "hospitalidad" del forastero en conexión directa con la sexualidad. Pero el modo en que LaCugna concibe esta visión "católica" de la sexualidad va más allá de las relaciones sexuales: el modelo de esta persona y esta sexualidad "católica" no es otro que Jesús de Nazaret, que no ha tenido miedo en incluir en su ministerio a las mujeres de su tiempo. ${ }^{54}$ Se trata —resulta evidente- de una perspectiva que no está exenta de problemas.

\section{LA TRINIDAD, MODELO ORIGINARIO DE FAMILIA}

Agustín encontró la imagen de Dios en las tres potencias del hombre. Desde allí, lograba encontrar un lenguaje válido para hablar de la

\footnotetext{
53 Cf. san Juan Pablo II, Carta apostólica Mulieris Dignitatem, 6-7, y el comentario de Angelo Scola, Hombre-Mujer. El misterio nupcial, Madrid, Encuentro, 2001, 34.

54 Cf. LaCugna, Dio per noi, 300-306, 352-353, 409-410.
} 
Trinidad. Pero no fue este el único camino esbozado por el Hiponense en su búsqueda de palabras que permitan decir la Trinidad de Dios. Al final del libro octavo del De Trinitate, nos invita a reconocer a la Trinidad en el amor, concretamente en la tríada de amante, amado y amor. ${ }^{55}$ Piero Coda reconoce la genialidad de Agustín: ha vislumbrado la fuerza teológica del misterio trinitario del amor iluminado por el amor humano en su dimensión interpersonal. El teólogo italiano no duda en calificar esta intuición agustiniana como"fruto de un don de lo alto". Sin embargo, Agustín no se adentra por el camino que acaba de descubrir, por miedo a que pueda insinuarse una visión triteísta del misterio santo de Dios. Los tiempos no estaban aún maduros para una visión interpersonal del amor trinitario. ${ }^{56}$ Será Ricardo de San Víctor, varios siglos después, quien emprenda el camino que abrió Agustín sin llegar a recorrerlo. ${ }^{57}$

La discreción con la que Agustín decide no seguir la perspectiva interpersonal contrasta con su rechazo frontal a quienes tratan de comparar la Trinidad de personas con los miembros de una familia: el padre de la familia representaría a Dios Padre, la madre sería el Espíritu Santo, mientras que el hijo que procede del padre por generación haría pensar en el Hijo eterno de Dios. ${ }^{58}$ El rechazo de Agustín, secundado por Tomás de Aquino, ${ }^{59}$ colocará bajo sospecha esta analogía familiar de la Trinidad en el Occidente cristiano. Solo poco a poco podrá encontrar su lugar en la teología contemporánea, a medida que se vaya consolidando una nueva forma de hablar de la Trinidad y se encuentren nuevos modos de expresar esta analogía familiar. ${ }^{60}$

Entre las propuestas más convincentes, podemos destacar a Hans Urs von Balthasar, que se fija en la conexión entre la unión sexual entre los esposos y el nacimiento de su hijo. Ambos momentos

55 Cf. san Agustín de Hipona, De Trinitate VIII,8-10 (CChr.SL 50,286-291).

56 Cf. Piero Coda, Dalla Trinità. L'avvento di Dio tra storia e profezia, Roma, Città Nuova 2011, 381-386.

57 Cf. Ricardo de San Víctor, La Trinidad (VeIm 203), Salamanca, Sígueme, 2015. De entre la abundante bibliografía, cf. Fidelis Den, Mensch, Analogie und Trinität. Eine Untersuchung des analogen Denkens in der Trinitätslehre von Augustinus, Richard von St. Viktor und Gisbert Greshake, Frankfurt - Bern - Paris - New York, Peter Lang, 2019, 83-143.

58 Cf. san Agustín de Hipona, De Trinitate XII, 5,5 (CChr.SL 50,359).

59 Cf. santo Tomás de Aquino, Summa Theologiae I q. 93, a. 6.

60 Cf. Alessio Melon, L'analogia familiare della Trinità. Il contesto, la storia, un bilancio, Assisi, Cittadella, 2019. 
están separados en el tiempo por los nueve meses de embarazo. Si pudiéramos prescindir mentalmente de esa distancia temporal, veríamos al hijo como fruto del amor recíproco de sus padres, un amor que va más allá de ambos y produce una vida nueva. En esta fecundidad matrimonial hay una preciosa parábola de la procesión del Espíritu Santo como amor del Padre y el Hijo. ${ }^{61}$

La propuesta de san Juan Pablo II es una de las más brillantes. Con él, la analogía familiar se incorpora a la enseñanza magisterial de la Iglesia. De todas sus intervenciones, destacamos su Carta a las Familias de 1994, donde afirma que"el modelo originario de la familia hay que buscarlo en Dios mismo, en el misterio trinitario de su vida. El «Nosotros» divino constituye el modelo eterno del «nosotros» humano [...] formado por el hombre y la mujer, creados a imagen y semejanza divina". ${ }^{62}$ Benedicto XVI y Francisco, sucesores de san Juan Pablo II como obispos de Roma, han recogido distintas formulaciones de esta analogía familiar trinitaria. ${ }^{63}$

Como puede observarse, hablar de la Trinidad desde la analogía familiar resulta posible desde una comprensión renovada de la imagen divina en el ser humano. Marc Ouellet, inspirándose en la teología de Balthasar y el magisterio de Juan Pablo II, ha podido proponer una "antropología trinitaria de la familia" ${ }^{64}$ La imagen familiar tiene gran fuerza evocativa para presentar el misterio trinitario a nuestros contemporáneos, a condición de que se observen algunas precauciones. Especialmente han de evitarse los paralelos entre tal persona divina y tal miembro de la familia humana. La analogía se establece entre la comunidad familiar y la comunión trinitaria, en las relaciones que hay entre los miembros, no entre los sujetos que las componen. ${ }^{65}$

\section{DE TRINITATE ECCLESIA}

La eclesiología es el ámbito donde la "trinitarización" de todo el saber teológico se ha hecho más evidente en los últimos decenios. Aunque en todas las épocas se ha expresado la relación entre Trinidad y

\footnotetext{
61 Cf. Hans Urs von Balthasar, Teológica vol. III: El Espíritu de la Verdad, Madrid, Encuentro, 1998, 162.

62 Cf. san Juan Pablo II, Carta Gratissimam sane, 6.

63 Referencias en MeLONI, L'analogia familiare della Trinità, 357-362.

64 Cf. Ouellet, "Divina Somiglianza", 9-105.

65 Cf. Meloni, L'analogia familiare della Trinità, 428.
} 
eclesiología, ${ }^{66}$ el Concilio Vaticano II puede señalarse como punto de inicio de esta"nueva conciencia trinitaria de la Iglesia". ${ }^{67}$

Hay una opción explícita del Concilio por hablar del misterio de la Trinidad desde el don que las divinas personas han realizado de sí mismas en la historia de la salvación. Así lo explica la Comisión Doctrinal del Concilio, respondiendo a las preguntas de algunos padres conciliares acerca de si lo que se afirmaba de las personas divinas había que entenderse como propio o apropiado. La Comisión se remitió al lenguaje bíblico, concretamente al primer capítulo de la carta paulina a los Efesios, señalando que "la revelación de la salvación por medio de la Iglesia se ofrece de acuerdo con la obra respectiva de las tres Personas [secundum munus trium Personarum]". ${ }^{68}$ Desde esta opción por el lenguaje bíblico, que habla de la Trinidad desde la actuación de las tres divinas personas en la historia de la salvación, el ConcilioVaticano II presentó a la Iglesia como un misterio que hunde sus raíces en el misterio santo de Dios Trinidad y obtiene su identidad profunda en Él. ${ }^{69}$

El diálogo ecuménico ha proporcionado un impulso notable a la búsqueda de las raíces trinitarias de la Iglesia. ${ }^{70}$ En especial, el diálogo con la teología ortodoxa ha sido muy fecundo para la renovación trinitaria de la eclesiología. Esta influencia del Oriente cristiano

66 En perspectiva histórica, cf. Domingo GarCía GullléN, “La Iglesia de la Trinidad. Una panorámica histórica", Facies Domini 3 (2011), 15-110; Heinz Schütre, "Kirche des dreieinigen Gottes. Zur trinitarischen Entfaltung der Ekklesiologie als Aufgabe", en Wilhelm Breuning - Michael BÖHNKE - Hanspeter HeINZ (eds.), Im Gespräch mit dem dreieinen Gott. Elemente einer trinitarischen Theologie, Düsseldorf, Patmos, 1985, 361-375.

67 Cf. Marie-Dominique Chenu, "Nueva conciencia del fundamento trinitario de la Iglesia", Concilium 17 (1981) 340-353.

68 Acta Synodalia Sacrosancti Concilii Oecumenici Vaticani II, vol. III/1, Città del Vaticano, 1973, 171. Cf. Nereo Silanes, "La Iglesia de la Trinidad". La Santísima Trinidad en el Vaticano II. Estudio genético-teológico (Koinonia, 14), Salamanca, Secretariado Trinitario, 1981, 99-104.

69 Cf. Concilio Vaticano II, Constitución dogmática Lumen Gentium nn. 2-4; Decreto Ad Gentes divinitus, nn. 2-4. Resulta muy interesante al respecto Gilles RouthieR, "Vatican II et le renouveau ecclésiologique de la théologie trinitaire", en Emmanuel Durand -Vincent Holzer (eds.), Les réalisations du renouveau trinitaire au XXe siècle (CFi 273), Paris, Cerf, 2010, 217-246.

70 Cf. Santiago Madrigal Terrazas, "La eclesiología trinitaria en perspectiva ecuménica", en Juan Pablo García Maestro (ed.), Trinidad, comunión y unidad. X Congreso Trinitario Internacional, Madrid, Paulinas, 2017, 53-88. 
se deja notar ya en los documentos del Concilio Vaticano II. ${ }^{71}$ Con más claridad aún se observa en el llamado "Documento de Múnich" (1982), fruto de la segunda reunión plenaria de la Comisión Mixta Internacional de Diálogo Teológico entre la Iglesia Católica Romana y la Iglesia Ortodoxa. Su título es suficientemente expresivo: "El misterio de la Iglesia y de la Eucaristía a la luz del misterio de la Santísima Trinidad". ${ }^{72}$ Veinticinco años después (2007), el documento de Rávena ha tratado de sacar consecuencias concretas para la organización de la Iglesia. ${ }^{73}$ Múnich mira la Iglesia desde el misterio trinitario, Rávena trata de configurar trinitariamente las estructuras visibles de la Iglesia.

Entre Trinidad e Iglesia existe una relación triple, que se puede resumir en la fórmula "Ecclesia de Trinitate". Fue propuesta a finales de los años treinta del siglo pasado por Yves Congar que decía que la Iglesia viene de la Trinidad (Ecclesia de Trinitate) y está compuesta de hombres (Ecclesia ex hominibus). ${ }^{74}$ Se inspiraba en la afirmación de san Cipriano, según la cual la Iglesia es un pueblo reunido "de unitate Patris et Filii et Spiritus Sancti". ${ }^{75}$ Desarrollando el sentido de este "de Trinitate", el belga Gérard Philips descubre una triple causalidad trinitaria de la Iglesia. La Trinidad es causa eficiente de la Iglesia; es causa formal (o cuasi-formal), porque inspira su configuración ministerial y jerárquica; y es causa final, porque la Iglesia camina hacia la Trinidad. ${ }^{76}$ Esta triple relación causal de la Iglesia con la Trinidad se expresa también en el citado Documento de Múnich (1982), que afirma: "la Iglesia encuentra su modelo, su origen y su fin en el misterio del Dios uno en tres personas". ${ }^{77}$ Bruno Forte ha tomado estas tres

71 Cf. Yannis SPITERIS, "La teología trinitaria ortodoxa como precomprensión de la Lumen Gentium", Estudios trinitarios 39 (2005) 427-448.

72 Cf. Comisión Mixta Internacional de Diálogo Teológico entre la Iglesia Católica Romana y la Iglesia OrtodoXa, “El Misterio de la Iglesia y de la Eucaristía a la luz del Misterio de la Santísima Trinidad", Diálogo ecuménico 18 (1984) 85-107.

73 Cf. COMisión Mixta InTERnACiOnal..., "Consecuencias eclesiológicas y canónicas de la naturaleza sacramental de la Iglesia. Comunión eclesial, conciliaridad y autoridad", Diálogo ecuménico 43 (2008), 307-323.

74 Cf. Yves Congar, Chrétiens désunis. Principes d'un "œcuménisme" catholique (UnSa 1), Paris, Cerf, 1937, 59-73.

75 San Cipriano de CARTAGo, De oratione dominica 23 (CSEL 3/1, 284-285).

76 Cf. Gérard PhiliPs, La Iglesia y su misterio en el Concilio Vaticano II, vol. I, Barcelona, Herder, 1968, 116.

77 Comisión Mixta Internacional..., "El Misterio de la Iglesia y de la Eucaristía...", 99. 
relaciones de la Trinidad y la Iglesia como principio de estructuración de su eclesiología: "la Trinidad es el origen, la forma y la patria de la unidad eclesial, la fuente de donde esta nace, la imagen en donde se inspira y la meta hacia la que se dirige en el camino del tiempo".$^{78}$

A continuación trataremos de ver cómo hay que entender concretamente que la Trinidad es origen, forma y destino de la Iglesia.

\subsection{Origen}

El Concilio Vaticano II presentó a la Iglesia como un misterio que brota del misterio Santo de Dios. Estamos ante un buen ejemplo del "nexus mysteriorum" propuesto por el primer Concilio Vaticano (DH 3016). La opción conciliar por hablar de la Trinidad secundum munus trium Personarum explica el protagonismo de los nombres de la Iglesia que la relacionan con cada una de las tres divinas personas: "Pueblo de Dios", "Cuerpo de Cristo" y"Templo del Espíritu". ${ }^{79}$ Para una interpretación verdaderamente trinitaria del origen de la Iglesia expresado en estos títulos, hay que considerar que el nombre de cada persona divina implica a las otras dos, pues la definición trinitaria de persona es relacional. Dios es Padre porque ha engendrado eternamente al Hijo y ha espirado junto con Él al Espíritu Santo. En la presentación teológica del origen trinitario de la Iglesia, una de las cuestiones fundamentales es la adecuada coordinación entre los distintos títulos trinitarios. A fin de que la Iglesia sea auténticamente de Trinitate ha de mantenerse el equilibrio de la relación de la Iglesia con cada una de las divinas personas. Los títulos trinitarios de la Iglesia se necesitan entre sí porque las personas divinas solo se entienden en su relación mutua.

Cuando se habla de la Iglesia como "Pueblo de Dios" es necesario acentuar que ése Dios es el "Dios y Padre de Nuestro Señor Jesucristo" (2 Cor 1,3; Ef 1,3; 1 Pe 1,3). Hablar solamente de "Dios" sin explicitar que se trata de "Dios Padre" difuminaría su relación fundamental con el Hijo y el Espíritu Santo. Una presentación explícitamente trinitaria del origen de la Iglesia ha de mostrar que ella es el

78 Bruno ForTe, La Iglesia de la Trinidad. Ensayo sobre el misterio de la Iglesia comunión y misión (Ágape 14), Salamanca, Secretariado Trinitario, 1996, 72. En la misma línea, cf. Marcello SEMERARo, Misterio, comunión y misión. Manual de eclesiología (Ágape 35), Salamanca, Secretariado Trinitario, 2004.

79 Cf. Concilio Vaticano II, Constitución dogmática Lumen Gentium, n. 17. 
"Pueblo de Dios Padre". La Iglesia nace de Dios Padre, de su iniciativa de salvar al género humano y reunirlo en una sola familia de hijos en el Hijo por el Espíritu Santo. San Pablo destaca que Dios envió al Hijo y el Espíritu para salvarnos (Gál 4,4-6). El notable esfuerzo del Concilio por situar el origen de la Iglesia en el designio salvador que viene de Dios Padre apenas se refleja en la bibliografía teológica. ${ }^{80}$

Las dos misiones divinas que brotan del Padre han de considerarse en su unidad, sin separar las economías del Hijo y el Espíritu. Esta afirmación trinitaria ha de tener su consecuencia en la elaboración de las eclesiologías. Tanto la referencia cristológica como la pneumatológica son esenciales al ser eclesial, sin que pueda excluirse ninguna de las dos. En el pasado, cierta teología ortodoxa ha señaló el déficit pneumatológico en la teología latina, hablando de "cristomonismo" o"cristologismo". La acentuación unilateral de la pneumatología ha sido habitual en las visiones protestantes de la Iglesia, y en algunos autores católicos del postconcilio. Hace falta una eclesiología verdaderamente trinitaria, más allá de las acentuaciones unilaterales de su origen cristológico y pneumatológico. ${ }^{81}$ Una propuesta interesante es la de quienes presentan a la Iglesia como el cuerpo de Cristo ungido por el Espíritu Santo. ${ }^{82}$

\subsection{Forma}

El documento de Múnich (1982), al presentar la relación entre el misterio eclesial y el misterio trinitario, afirma que"los elementos institucionales (de la Iglesia) no deben ser más que un reflejo visible de

80 Entre las pocas excepciones: José Arturo Domínguez Asensio, "La Iglesia del Padre, una familia de hijos", Communio (Sevilla) 32 (1999) 235-271; Reinhard KNITTEL, "La Chiesa «popolo del Padre». Alcune considerazioni sulla prospettiva "patro-nomica» della Chiesa", Lateranum 66 (2000) 217-234; Jean Marie Roger Tillard, Iglesia de Iglesias (VeIm 113), Salamanca, Sígueme, 1991, 56-64; François Xavier Durrwell, Nuestro Padre. Dios en su misterio (VeIm 110), Salamanca, Sígueme, ${ }^{2} 1992$, 75-104 ("La Iglesia que está en Dios Padre").

81 Cf. Heribert MüHLEN, El Espíritu Santo en la Iglesia. La Iglesia como el misterio del Espíritu Santo en Cristo y en los cristianos: "una persona en muchas personas" (Koinonia 1), Salamanca, Secretariado trinitario, ${ }^{2} 1998$, xVIII y 477.

82 Junto con el clásico estudio de Mühlen, que acabamos de citar, puede leerse Cettina Militello, La Chiesa, "il corpo crismato". Trattato di ecclesiologia (CTSis 7), Bologna, Dehoniane, 2003. 
la realidad mistérica". ${ }^{83}$ Como afirmación de principio resulta difícil discutirla, aunque hay menos consenso en el modo en que ha de entenderse esta relación entre misterio de la Trinidad y estructura visible de la Iglesia. Creo que podemos distinguir tres propuestas de estructuración trinitaria de la Iglesia.

Una primera línea de reflexión la encontramos en el seno del diálogo teológico entre católicos y ortodoxos, tratando de sacar consecuencias concretas de la fundamentación teológica establecida en el documento de Múnich. Para ello, el documento de Rávena (2007) recupera un canon de las Constituciones apostólicas, una regulación eclesiástica que data del último tercio del siglo cuarto de nuestra era, y que fue redactado probablemente en Siria. El canon 34 de estas constituciones trata de regular la relación entre el obispo metropolitano de cada nación y el resto de obispos. A este obispo principal se le denomina "primero [protos]" y "cabeza [kefalé]" de los demás obispos. ${ }^{84}$ Se afirma así un primado que es compatible con la sinodalidad o comunión entre los obispos. El documento de Rávena propone extender estas dimensiones de primado y conciliaridad a los tres niveles existentes en la Iglesia: local, regional y universal. En el nivel local, el obispo es el primero respecto a sus presbíteros y su pueblo. A nivel regional, cada obispo metropolitano es protos respecto al resto de obispos de su provincia; a la vez, los patriarcas de las cinco sedes principales (Roma, Constantinopla, Alejandría, Antioquía y Jerusalén) ejercen como protos entre los metropolitanos de su circunscripción. Finalmente, en la Iglesia universal, el obispo de Roma ejerce como protos entre los cinco patriarcas. Este primado en los tres niveles de la Iglesia no contradice la conciliaridad, del mismo modo en que la comunión trinitaria no se rompe por el hecho de que el Padre sea el primero [protos], origen del Hijo y el Espíritu Santo. Tanto en la Trinidad como en la Iglesia existe un orden [taxis]. ${ }^{85} \mathrm{El}$ teólogo ortodoxo griego Ioannis Zizioulas aportó esta propuesta de radicación trinitaria de la estructura de la Iglesia al grupo de diálogo

\footnotetext{
Comisión Mixta Internacional...,"El Misterio de la Iglesia y de la Eucaristía...", 99. 4 Cf. Constituciones apostólicas VIII,47,34: ed. Juan José AyÁn CALVO, Biblioteca de Patrística 82, Madrid, Ciudad Nueva, 2010, 352.

85 Cf. Comisión Mixta Internacional...,"El Misterio de la Iglesia y de la Eucaristía...", nn. 5,44 .
} 
reunido en Rávena. ${ }^{86}$ Se trata de una aportación coherente con la eclesiología del autor, que establece una estrecha relación entre el lugar del ministerio ordenado dentro de la Iglesia y la situación del Padre dentro de la comunión trinitaria. ${ }^{87}$

Esta primacía del Padre, con sus consecuencias para la estructuración eclesial, no convence a los teólogos que prefieren una eclesiología más igualitaria, inspirada en una teología trinitaria de la "comunión". El término"comunión" tiene la ventaja de poder aplicarse tanto a la Iglesia como a la Trinidad. Como categoría eclesiológica, apareció en el panorama teológico en los años del Concilio Vaticano II, y se consolidó en los años ochenta del siglo pasado. ${ }^{88}$ Más tarde comenzó a generalizarse su uso en teología trinitaria. ${ }^{89}$ Gisbert Greshake ha estructurado toda su teología poniendo como cimiento la communio. Dios mismo es communio, indica Greshake, "aquella communio en la que las tres personas divinas, en un intercambio trialógico de amor, realizan la vida divina una como comunicación recíproca de sí mismas". ${ }^{90} \mathrm{~A}$ imagen de esta communio trinitaria ha de estructurarse la communio eclesial. Las diferencias entre los miembros de la Iglesia, como las referidas a los ministerios y la autoridad, están siempre al servicio de la comunión de los hombres con Dios y de los hombres entre sí. En la Trinidad se da la perijóresis: la única esencia divina existe en las tres personas y está entera en cada una de ellas. Cada una de las personas divinas - en la visión trinitaria de Greshake - recibe la vida divina de las otras y se la entrega. De ahí que no pueda aceptarse una primacía de Dios Padre. A imagen de la Trinidad, cada uno de los miembros de la Iglesia"posee su realidad más honda en la recepción del todo y en la entrega al todo de la red multiforme" ${ }^{\prime 1}$

86 Así lo señala el cardenal Kasper, presidente católico de la comisión, cf. Walter Kasper - Daniel Deckers, Wo das Herz des Glaubens schlägt. Die Erfahrung eines Lebens, Freiburg - Basel - Wien, Herder, 2008, 223.

87 Cf. Ioannis Zizioulas, Comunión y alteridad. Persona e Iglesia (VeIm 178), Salamanca, Sígueme, 2009, 185-190.

88 Cf. Salvador PIé i NinOt, Eclesiología. La sacramentalidad de la comunidad cristiana (LuxMu 86), Salamanca, Sígueme, 2007, 160-170.

89 Cf. Stefan Mangnus, "God as communion. The meaning of «communion» in contemporary trinitarian theology», Bijdragen 64 (2003) 39-67.

90 GreshaKe, El Dios uno y Trino, 223.

91 GreshaKe, El Dios uno y Trino, 454. 
No han faltado críticas a esta eclesiología trinitaria de la comunión, por olvidar que Trinidad e Iglesia no son"comunión" en el mismo sentido. El Concilio IV de Letrán (1215) había afirmado que"no puede afirmarse tanta semejanza entre el Creador y la criatura sin que haya de afirmarse entre ellos una mayor desemejanza" (DH 806). El texto conciliar se cita a menudo sin explicar su contexto inmediato. El Lateranense cuarto quiso marcar la diferencia entre la unidad eclesial y la unidad trinitaria, dando la razón a Pedro Lombardo frente a Joaquín de Fiore. ${ }^{92}$ La dificultad de estas teologías de la communio es el propósito (declarado o no) de ensalzar la igualdad fundamental de todos los miembros, ministerios y servicios en la Iglesia, proyectando en el ser divino un determinado modelo eclesiológico. Para salvar el escollo, algunos autores han comenzado a proponer una eclesiología trinitaria que no tenga su base en la communio. ${ }^{93}$

\subsection{Destino}

La constitución conciliar Lumen Gentium ha dedicado un capítulo completo (el VII) al carácter escatológico de la Iglesia, aunque toda ella está impregnada de la convicción de que la Iglesia está en camino hacia Dios. La Iglesia vive entre la primera venida de Cristo y la segunda. Una gran virtud de Lumen Gentium es que este carácter peregrinante de la Iglesia se subraya con tonos inequívocamente trinitarios. ${ }^{94}$ Puede establecerse un paralelo entre el capítulo primero, que sitúa las raíces de la Iglesia en el misterio trinitario de Dios, y el séptimo, donde se acentúa su destino trinitario. La"Iglesia de Trinitate" es también"Ecclesia ad Trinitatem".$^{95}$ La Iglesia nace de la Trinidad y vive en camino hacia la Trinidad.

92 Cf. Giacomo Canobbio, "Unità della Chiesa, Unità della Trinità", en Fernando Chica Arellano - Sandro Panizzolo - Harald Wagner (eds.), Ecclesia tertii millenii advenientis. Omaggio al p. Angel Anton, Casale Monferrato, Piemme, 1997, 29-45.

93 Cf. Neil Ormerod, "A (non-communio) Trinitarian ecclesiology: Grounded in grace, lived in faith, hope, and charity", Theological Studies 76 (2015) 448-467: <DOI: 10.1177/0040563915593470>; Ligita RYLIŠKYTĖ, "Non-Communio Trinitarian Ecclesiology. Furthering Neil Ormerod's Account", Irish Theological Quarterly 83 (2018) 107-127: <DOI: 10.1177/0021140018757880> [Consulta: 7 abr. 2021].

94 Cf. ConcilioVaticano II, Constitución dogmática Lumen Gentium, nn. 17.47.51.69.

95 Cf. Charles Journet, Per una teologia ecclesiale della storia della salvezza, Napoli, D'Auria, 1972, 929. 
La Iglesia realiza su ser trinitario de la misión: al ser peregrina, está llamada a anunciar a cada hombre y mujer el misterio santo del que ella misma brota. Nace de las misiones del Hijo y del Espíritu al mundo, y del envío misionero de Jesús, que también tiene forma trinitaria: "como el Padre me ha enviado, así también os envío yo; recibid el Espíritu Santo" (Jn 20,21). El camino de la Iglesia le permite actualizar su ser misionero en el tiempo. Su camino histórico se sitúa entre la misión trinitaria que le origina y el destino trinitario al que se encamina. Por eso, la misión de la Iglesia es trinitaria: ella"se siente impulsada [...] por el Espíritu Santo a colaborar a que se lleve a cabo el plan de Dios que constituyó a Cristo principio de salvación para todo el mundo". ${ }^{96}$

En el ámbito de la celebración litúrgica se experimenta con fuerza la identidad escatológica de la Iglesia. ${ }^{97}$ Celebrando el misterio de Jesucristo, la Iglesia experimenta que todo le viene del Padre, por el Hijo en el Espíritu. En el Espíritu, por el Hijo tenemos acceso al Padre. ${ }^{98}$ Este doble movimiento trinitario (descendente y ascendente) que experimentamos en la liturgia se corresponde con el origen y el destino de la Iglesia en la Trinidad. Una eclesiología trinitaria necesita alimentarse de una comprensión teológica de la liturgia. En efecto, la celebración litúrgica, especialmente la eucaristía, es la principal manifestación de la Iglesia. ${ }^{99}$ De ella se alimenta continuamente la vida eclesial. La vocación escatológica de la Iglesia no podrá comprenderse sin una adecuada eclesiología litúrgica, que está dando sus primeros frutos. ${ }^{100}$

\section{6. "LA TRINIDAD SERÁ NUESTRO PROGRAMA SOCIAL"}

Otro de los ámbitos en los que la teología se ha hecho más significativamente trinitaria es la vida social. Entendemos "social" en un

\footnotetext{
96 Cf. Concilio Vaticano II, Constitución dogmática Lumen Gentium, n. 17.

97 Cf. Concilio Vaticano II, Constitución Sacrosanctum Concilium, nn. 8.83.120.122.

98 Cf. Domingo García Guillén, "Por una teología trinitaria más inspirada en la liturgia", Estudios trinitarios 51 (2017) 239-288.

99 Cf. Concilio Vaticano II, Constitución Sacrosanctum Concilium, nn. 2 y 41.

100 Cf. Nathan Mrtchell, "Ecclesiologia liturgica", en Ansgar J. Chupungco (ed.), Scientia liturgica. Manuale di liturgia, vol. II, Casale Monferrato, Piemme, 1998, 119-134; María del Pilar Río, Chiesa e liturgia. Apporti del movimento liturgico al rinnovamento ecclesiologico della prima metà del XX secolo, Roma, EDUSC, 2020.
} 
sentido amplio, que incluye la economía, la política y los modos de organización comunitaria. Hemos hablado ya del meritorio intento de Catherine Mowry LaCugna por mostrar la dimensión "práctica" de la Trinidad de Dios, en ámbitos como la sexualidad, la política o la economía. ${ }^{101}$ Esta reivindicación del carácter práctico de la doctrina trinitaria ha de entenderse como una respuesta a la conocida acusación formulada por Kant:

Del dogma de la Trinidad, tomado literalmente, no cabe forjar absolutamente nada en función de lo práctico [...] Si hemos de venerar a tres o a diez personas representa una cuestión que el discente aceptará literalmente con igual facilidad tanto en un caso como en el otro, puesto que carece de concepto alguno sobre un Dios pluripersonal hipostasiado, pero sobre todo porque no puede sacar regla alguna para su conducta a partir de semejante multiplicidad. ${ }^{102}$

La reivindicación del carácter "práctico" de la doctrina trinitaria o su aplicación a los ámbitos sociales aparece frecuentemente de la mano de una frase acuñada por Nikolai F. Fédorov, filósofo ruso de finales del siglo xIx: "el dogma de la Trinidad es nuestro programa social" ${ }^{103}$ Varios autores han asumido la tarea de formular una teología trinitaria con implicaciones sociales. Destacamos tres autores, vinculados a tres tradiciones cristianas distintas: el evangélico alemán Jürgen Moltmann, el ortodoxo indio Geevarghese Mar Osthathios y el católico brasileño Leonardo Boff. Con acentos diversos, estos autores señalan la necesidad de que la doctrina trinitaria inspire los modelos de organización económica y social. ${ }^{104}$ Jürgen Moltmann es muy crítico con la imagen monárquica y patriarcal de Dios que tiene al Padre como origen; en su lugar, propone una Trinidad

101 Cf. LaCugna, Dio per noi, 373-414.

102 Immanuel KANT, El conflicto de las facultades en tres partes, Madrid, Alianza, ${ }^{2} 2020$, 107.

103 Cf. Miroslav Volf, "«The Trinity Is Our Social Program». The Doctrine of the Trinity and the Shape of Social Engagement", Modern Theology 14 (1998) 403423: <DOI:10.1111/1468-0025.00072> [Consulta: 7 abr. 2021].

104 Cf. Bernd Jochen HiLBERATH, Der dreieinige Gott und die Gemeinschaft der Menschen. Orientierungen zur christlichen Rede von Gott, Mainz, Grünewald, 1990, 63-77; Santiago Del Cura Elena, "Relevancia social y política de la teología trinitaria: exposición y comentario", Corintios XIII 94 (2000) 109-139. 
entendida como comunión del Padre y el Hijo y el Espíritu Santo. ${ }^{105}$ Mar Osthathios, desde la dolorosa experiencia india de una sociedad dividida en castas, contempla la imagen divina presente en cada ser humano como factor de igualdad entre todos los hombres, que ha de traducirse en un proyecto de justicia social y un modelo de acción sociopolítica: una sociedad sin clases, una única familia humana inspirada en el modelo de la Trinidad Santa. ${ }^{106}$ Desde la fe trinitaria, Leonardo Boff somete a evaluación los dos sistemas políticos y económicos dominantes: el individualismo capitalista contradice la comunión trinitaria, mientras que el socialismo tiene un modelo de sociedad colectivista, que no presta atención a las diferencias entre las personas y las relaciones que estas necesitan establecer. ${ }^{107} \mathrm{~A}$ estos tres nombres podríamos añadir la teología trinitaria de Gisbert Greshake, de la que hemos hablado antes. ${ }^{108}$

Moltmann, Boff y Greshake proponen una doctrina trinitaria con incidencia social. Los tres establecen una estrecha vinculación entre el modo de concebir la Trinidad divina y el modo en que una sociedad se organiza. A fin de proporcionar base teológica a las sociedades democráticas y participativas, los tres autores optan por un modelo trinitario basado en la mutua perichóresis o communio de las personas divinas. Esta visión de Dios ilumina la existencia de comunidades políticas en las que todos los miembros son iguales y están llamados a participar y colaborar en la construcción común.

El referente histórico-teológico de esta vinculación entre teología trinitaria y visión política es el conocido artículo de Erik Peterson El monoteísmo como problema político [1935]. ${ }^{109}$ En pleno auge de la ideología nacional-socialista, Peterson trataba de mostrar la vinculación entre una concepción unitaria de Dios y las visiones absolutistas de lo político. La tesis petersoniana ha sido contestada en su pertinencia histórica y teológica. ${ }^{110}$ Aún así, se cita con frecuencia para

105 Cf. Jürgen Moltmann, Trinidad y Reino de Dios. La doctrina de la trinidad (VeIm 80), Salamanca, Sígueme, ${ }^{21} 1986,207-238$.

106 Cf. Geevarghese Mar Osthathios, Theology of a Classless Society, New York, Maryknoll, 1980.

107 Cf. Leonardo Boff, La Trinidad, la sociedad y la liberación, Madrid, Paulinas, 1987, 184-190.

108 Cf. Greshake, El Dios uno y Trino, 547-583 ("Sociedad y Trinidad").

109 Cf. Erik Peterson, El monoteísmo como problema político, Madrid, Trotta, 1999.

110 Cf. Christoph Theobald, “La foi trinitaire des chrétiens et l'énigme du lien social. Contribution au débat sur la «théologie politique»", en Paul Beauchamp (ed.), 
vincular las visiones unitarias de lo divino con el poder absoluto. No es casualidad que Umberto Eco pusiera el nombre de "Práxeas" (un hereje monarquiano del siglo tercero) al jefe de los eunucos de su novela, verdadero gobernante en la sombra. La crítica teológica de Peterson sirve de ayuda a quienes quieren proponer una teología trinitaria de la comunión como sustento o apoyo de una determinada visión económica, política o social.

Las propuestas citadas hasta el momento someten a revisión los distintos modelos económicos, políticos y sociales desde los principios de la fe trinitaria. Algunos autores han querido dar un paso más allá, realizando propuestas concretas en estos ámbitos. Podemos destacar el libro del teólogo argentino Enrique Cambón La Trinidad, modelo social. Desde el carisma del movimiento de los focolares, centrado en la unidad, trata de explicitar" qué puede significar concretamente actuar según un estilo de vida pericorético-trinitario en los distintos ámbitos de la vida interpersonal y social" ${ }^{111}$ En lo referente al ámbito de la organización social y política, hay contribuciones recientes que tratan de fundar trinitariamente las democracias liberales modernas. ${ }^{112}$

\section{RIESGO Y PROMESA DE UNA TEOLOGÍA “TRINITARIA"}

El"espléndido aislamiento" denunciado por Rahner a mitad del siglo pasado ha dejado paso, en los albores del presente milenio, a una afirmación radicalmente opuesta: "tutto oggi è trinitario". ${ }^{113}$ Se podrá objetar que esta renovación trinitaria de los tratados teológicos está incompleta o debe desarrollarse todavía. ${ }^{114}$ Aún así, creo que nuestra exposición ha mostrado que hay mucho camino recorrido para que la Trinidad vuelva a ser el centro de inspiración de los tratados teológicos. Creo que hay tres aspectos a considerar como conclusión abierta

Monothéisme et Trinité, Bruxelles, Presses de l'Université Saint-Louis, 1991, 99137 : <DOI:10.4000/books.pusl.16764> [Consulta: 7 abr. 2021].

111 Enrique CAmbón, La Trinidad, modelo social, Madrid, Ciudad Nueva, 2000, 153.

112 Cf. Antonio Aurelio FERNÁNDEZ SERRANo, Libertad, comunión, verdad. Las sociedades democráticas como reflejo de la Trinidad (Koinonia 56), Salamanca, Secretariado trinitario, 2017; Otmar MeufFels, Christsein im demokratischen Handeln. Trinitarische Einsichten, gesellschaftliche Interessen (RPT 96), Tübingen, Mohr Siebeck, 2018.

113 Antonio Staglianò, "Teologia trinitaria", 91.

114 Cf. Anne Hunt, Trinity. Nexus of the Mysteries of Christian Faith, Maryknoll, Orbis Books, 2005. 
de estas reflexiones y provocación para otras nuevas.

a) En primer lugar, hay que reconocer que la renovación ha traído aspectos preocupantes o excesos que llaman la atención de cualquier observador sereno. Las propuestas económicas, sociales y políticas a las que nos hemos referido antes suscitan la duda de si es legítimo atribuir a la Trinidad un carácter "democrático" o discernir los distintos sistemas económicos o políticos desde una determinada visión del misterio de Dios. Tanto LaCugna como Greshake, que se han destacado por una teología totalmente inspirada por el misterio trinitario, han advertido del riesgo de pretender un reflejo demasiado directo de la Trinidad en la economía, la sociedad o la política. Además de utilizar el misterio de Dios para fines espurios, una teología así faltaría al respeto a la legítima autonomía de las realidades humanas. ${ }^{115}$ Lo mismo habría que decir de ciertas eclesiologías, que para defender un determinado modelo de Iglesia, buscan ideas trinitarias coincidentes: afirman de Dios aquello que opinan de la Iglesia, como sucede con algunas eclesiologías de "comunión" ${ }^{116}$ Karen Kilby ha mostrado algo similar en algunos defensores del modelo social de la Trinidad. Comienzan señalando la"perijóresis" como aquello que une las tres personas, sin definir muy bien en qué consiste. Posteriormente, llenan este concepto con ideas positivas de la experiencia humana de comunidad y relación. Por último, señalan que este modelo trinitario es un recurso magnífico para las comunidades y la teología cristiana. ${ }^{117}$

Este "mecanismo de proyección" señalado por Kilby supone un uso interesado del misterio santo de Dios para legitimar las propias ideas sobre la sociedad, la Iglesia o el ser humano. La advertencia del Lateranense IV invita a marcar la distancia siempre que pongamos en relación (analogía) la realidad divina y las realidades humanas. ${ }^{118}$

115 Cf. Greshake, El Dios uno y Trino, 519-520. 554-557; LaCugna, Dio per noi, 375, 404.

116 Cf. Giacomo Canobbio, "La Trinità e la Chiesa", en Orazio Francesco Piazza (ed.), La Trinità e la Chiesa. In dialogo con Giacomo Canobbio (RdT.L 9), Cinisello Balsamo, San Paolo, 2006, 25-77.

117 Cf. Karen KILBY, "Perichoresis and Projection: Problems with Social Doctrines of the Trinity", New Blackfriars 81 (2000) 432-445: <DOI:10.1111/j.1741-2005.2000. tb06456.x> [Consulta: 7 abr. 2021].

118 Sobre el riesgo de "funcionalización"de Dios, conviene leer una y otra vez las inspiradas páginas de Olegario GonzÁlez De CARdedal, Dios (VeIm 165), Salamanca, Sígueme, 2004, 197-255. 
El afán por incorporar una dimensión trinitaria a toda reflexión teológica no puede hacerse a costa de sacrificar la gratuidad divina y su diferencia respecto de nosotros.

Igualmente ilegítimo sería privar de su dignidad propia a las realidades humanas, como si estas fueran mera deducción o derivación de la realidad trinitaria de Dios. No se puede ensalzar a Dios a costa de reducir al ser humano y su mundo a la insignificancia. Pienso en la certera crítica de Heinz Zahrnt a la teología matrimonial de Karl Barth. ${ }^{119}$ Este riesgo asoma en otros teólogos que sostienen (si es posible llamarla así) una analogía descendente. Y esto nos lleva a la segunda consideración.

b) Karl Barth muestra una forma descendente de analogía: partiendo de la Trinidad, proyecta sobre las realidades humanas la luz del amor de Dios, manifestado en Jesucristo que habita en el hombre por la acción del Espíritu Santo. Hans Urs von Balthasar ha llamado "katalogía" a este camino descendente. ${ }^{120}$ Se trata de un movimiento imprescindible, que expresa la prioridad de Dios en su acercamiento al ser humano (Rom 11,35: "¿quién le ha dado primero para tener derecho a la recompensa?"). ${ }^{121}$

Esta prioridad del camino descendente, que va de Dios a las criaturas, se observaba bien en el discurso trinitario de Agustín: podemos hallar la huella de Dios en el alma humana porque Dios nos creó a imagen y semejanza suya. Pero a la vez, esa imagen de Dios en el hombre nos permite hablar de la Trinidad empleando analogías humanas. Este último es el camino ascendente, llamado propiamente

119 "Barth interpreta el vis a vis entre hombre y mujer como una repetición del existente en la Trinidad y como una copia de la relación entre Cristo y su comunidad. La cuestión es qué es lo primero y qué lo segundo. ¿Ha creado Dios el matrimonio porque ha querido el matrimonio como dualidad de hombre y mujer, o bien lo ha creado Dios porque quería una analogía de la relación intratrinitaria y de la historia de la salvación? En el primer caso, el matrimonio es una estructura terrena querida por Dios, que tiene sentido y dignidad en sí misma, y si a uno le gusta, puede todavía además especular sobre ella como analogía de la estructura celeste; en el segundo caso, el matrimonio no es más que un material terreno modelado por Dios para copiar en él la estructura del cielo. Al subirnos hasta el cielo con sus especulaciones trinitarias, Barth nos retira el suelo en que pisamos": Heinz ZAHRNT, A vueltas con Dios. La teología protestante en el siglo XX, Zaragoza, Hechos y Dichos, 1972, 120-121.

120 Cf.Von Balthasar, Teológica, vol. II, 169-210.

121 Una preciosa aplicación del método "katalógico"a la antropología teológica nos ofrece OuelLet, "Divina Somiglianza", 26, 144, 217. 
"analogía", que permite hablar de Dios desde diversas realidades humanas: la estructura tripartita del alma, la familia o la sociabilidad del hombre. Siempre es legítimo este camino ascendente porque Dios mismo se ha expresado en la historia humana de Jesucristo:"A Dios nadie lo ha visto jamás: Dios unigénito, que está en el seno del Padre, es quien lo ha dado a conocer [exegésato]" (Jn 1,18).

Ambos caminos, ascendente y descendente, analogía y katalogía, son complementarios y se necesitan el uno al otro. Para no modelar a Dios a imagen y semejanza del hombre hay que situar la prioridad en la vía descendente. A fin de no convertir la existencia humana en una derivación insignificante de lo divino, hay que reconocer la legítima autonomía de las realidades terrenas sin dejar de reconocer la huella de Dios en sus criaturas.

Esta doble vía (ascendente y descendente) tiene su consecuencia en la estructuración de los tratados teológicos. Examinando las distintas realidades que se dejan pensar a la luz del misterio trinitario (hombre, familia, Iglesia, sociedad) hemos podido comprobar que también ellas permiten pensar la Trinidad y sirven de analogía válida para expresar el misterio de Dios. Históricamente, la renovación de la teología de la Trinidad solo pudo llegar tras el surgimiento de enfoques nuevos en otros tratados (eclesiología, cristología). La iluminación entre la Trinidad y las otras realidades es, así pues, recíproca aunque asimétrica.

Se observa bien en el caso de la familia. La Trinidad puede explicarse (con las debidas cautelas) como una familia. La familia humana, a su vez, es un icono viviente de la Trinidad. Entre ambas existe una relación asimétrica, puesto que se ponen en relación la vida de Dios y la de los hombres, la comunión divina y una realidad creatural. Pero se trata de una relación que circula en ambas direcciones: en sentido descendente o kata-lógico, porque la Trinidad es fuente que inspira y alimenta la vida familiar; se puede igualmente encontrar en la familia una imagen lograda de la comunión trinitaria (analogía ascendente). ${ }^{122}$

Algo similar podría decirse de la eclesiología, puesto que la Ecclesia de Trinitate aparece ya como un capítulo más de muchos tratados de teología de la Trinidad. ${ }^{123}$ A partir del nexo con el misterio

122 Cf. Carlo Rochetta, Teologia della famiglia. Fondamenti e prospettive, (CNST 97), Bologna, Dehoniane, 2011, 189.

123 Cf. Nicola Ciola, Teologia trinitaria. Storia. Metodo. Prospettive (CNST 39), Bologna, Dehoniane, 1996; Giordano FrosinI, La Trinità, mistero primordiale 
de la Iglesia, puede comprenderse mejor el misterio santo del Dios uno y trino.

Un caso muy distinto son las analogías trinitarias de la sociedad y la organización política. La experiencia de comunión con el Padre, el Hijo y el Espíritu Santo puede servir de alimento y animar a los cristianos para construir un mundo más fraterno y humano. La Iglesia podrá ser como un "vivero" de humanidad, un lugar donde comenzar a vivir a pequeña escala los valores que deberían reinar en la sociedad. Un proyecto que expresa muy bien una de las plegarias eucarísticas por diversas circunstancias:"Que tu Iglesia sea un vivo testimonio, de verdad y libertad, de paz y de justicia, para que todos los hombres se animen con una nueva esperanza".${ }^{124} \mathrm{El}$ misterio trinitario actúa en los creyentes y en la Iglesia, pero resulta difícil sostener una directa inspiración trinitaria para la sociedad y la economía que no pase por aquellas dos. La Trinidad solo puede convertirse en "programa social" a través de adecuadas mediaciones personales y eclesiales. ${ }^{125}$

c) La tercera consideración se refiere al tipo de teología trinitaria que mejor puede inspirar la teología de nuestro tiempo. En las primeras páginas de nuestra exposición recordábamos la decisiva contribución de Rahner para que la teología trinitaria saliera de un estancamiento de siglos. Junto a la superación del aislamiento respecto al resto de tratados y de otros aspectos de la vida cristiana, Rahner proponía volver a la historia de la salvación, la oikonomia salutis. Se trata de una adquisición irrenunciable, un nuevo punto de partida para la reflexión sobre el misterio de Dios; también para la irradiación trinitaria sobre el resto de los tratados.

Me parece ejemplar el camino que ha seguido la fundamentación trinitaria de la eclesiología. El Concilio Vaticano II fundaba su discurso trinitario en la revelación bíblica ("secundum munus trium Personarum"). Pasados más de cincuenta años de la clausura del Concilio, podemos reconocer como un acierto indudable su opción

(CNST.Manuali), Bologna, Dehoniane, 2000; Giuseppe Marco SALVATI, Io uno e trino. La Trinità come modello del cristiano, Napoli, Editrice Domenicana Italiana, ${ }^{3} 2011$.

124 Misal Romano. Tercera edición típica, Madrid, Libros Litúrgicos, 2016, 639.

125 Cf. Staglianò, "Teologia trinitaria”, 161. Expresa una opinión similar Frederick Christian Bauerschmidt, "The Trinity and Politics", en Gilles EmerY - Matthew Levering (eds.), The Oxford Handbook of the Trinity, Oxford, Oxford University Press, 2011, 531-543. 
de buscar las raíces de la eclesiología en una teología trinitaria pegada a la historia de la salvación, vinculada a la acción de las personas divinas en la historia, y no en una especulación trinitaria inmanente ${ }^{126}$. Desde la celebración del Concilio, la mayor parte de las eclesiologías que han propuesto una fundamentación trinitaria de la Iglesia toman como punto de partida la Trinidad manifestada en la historia de Jesús de Nazaret. ${ }^{127}$ Sin duda, ha tenido mucho que ver la secuencia en la que los tratados teológicos han ido actualizando sus contenidos en las décadas inmediatamente posteriores al Concilio: primero la eclesiología, después la cristología y finalmente la teología trinitaria. Cuando el foco de la renovación teológica se puso en el misterio trinitario de Dios, ya se había afianzado una tendencia a hablar de Dios desde la economía salvífica. La teología trinitaria pudo beneficiarse de la abundante reflexión exegética de la que ya se estaba nutriendo la cristología. Podrá alegarse -y con razón- que algunas cristologías eran deficientes desde el punto de vista dogmático, y también (por qué no reconocerlo) en lo que respecta a la solidez sistemática de sus propuestas. Tal vez solo en los últimos años hemos comenzado a leer cristologías que toman en serio la investigación sobre el Jesús histórico sin renunciar a una comprensión sistemática del misterio del Hijo de Dios hecho carne, siendo responsables con la tradición teológica de la Iglesia. ${ }^{128}$ Pero la teología trinitaria de la que bebió la eclesiología para poner sus fundamentos había comenzado a estar más atenta a la historia de la salvación, o si se quiere, más

126 Cf. Salvador Pié i Ninot, "Trinidad económica y origen de la Iglesia en el Vaticano II", Revista catalana de teología 40 (2015) 181-200.

127 En su ensayo sobre la metodología eclesiológica señala Dianich que todavía pueden encontrarse algunas eclesiologías fundadas en la Trinidad eterna, aunque no señala cuáles. Como respuesta propone una eclesiologia trinitaria que tenga como punto de partida la historia trinitaria de Dios (como dice Jürgen Moltmann):"Sembra [...] sia necessario impostare la riflessione sempre a partire [...] della vicenda di Gesù di Nazaret, nella quale il mistero della Trinità si svela, e non dalla pura contemplazione dell'Uno che vive la relazione delle tre persone": Severino Dianich, "Sui problemi del metodo in ecclesiologia", en Antonio BARrufFo (ed.), Sui problemi del metodo in ecclesiologia. In dialogo con Severino Dianich (RdT.L 8), Cinisello Balsamo, San Paolo, 2003, 21-53 (aquí 27).

128 Un buen ejemplo parece ser el primer tomo de la propuesta de Gabino URíBARRI Bilbao, El Hijo se hizo carne. Cristología fundamental (VeIm 218), Salamanca, Sígueme, 2021. Con todo, el juicio definitivo debería esperar hasta que la obra esté completa. 
atenta a la cristología. Por supuesto, también la cristología ha salido muy enriquecida por su encuentro con la reflexión trinitaria. ${ }^{129}$

En cambio, en otros ámbitos de la teología resultan más habituales los discursos especulativos basados en la Trinidad eterna. Sucede así en muchas propuestas de fundamentación trinitaria de la antropología teológica o la teología de la familia. La Trinidad que se quiere poner en relación con el hombre o la familia es, primordialmente, la Trinidad de las relaciones eternas. El resultado de esta opción teológica es una búsqueda de arquetipos trinitarios en las realidades humanas que no se preocupa lo suficiente por enraizar cristológicamente su discurso. La fundación intratrinitaria de la imagen divina será siempre una opción legítima, como muestra la impresionante propuesta agustiniana de encontrar la huella de la Trinidad en el alma. Pero creo que sería más enriquecedor para la teología contemporánea que, al hablar de la Trinidad, su referencia constante fuera la historia de la salvación, tal y como se ha manifestado en la vida de Jesús de Nazaret, que nos revela el rostro paterno de Dios y nos ofrece el don del Espíritu Santo. La búsqueda de estos arquetipos en la Trinidad eterna se ve aquejada de un déficit cristológico, por el olvido de la economía de la salvación. Se habla de la Trinidad sin referencia a la encarnación de Cristo y la importancia de sus misterios para la vida trinitaria de Dios. ${ }^{130}$ Pero este déficit cristológico de la reflexión

129 Léanse las breves pero enjundiosas consideraciones de Olegario GonZÁLEZ DE CARDEDAl, Fundamentos de Cristología, vol. I: El Camino. Madrid, BAC, 2005, 87-88 ("Cristo desde el Padre y desde el Espíritu").

130 Tal vez sería de ayuda una mayor atención a las sugerencias de la Comisión Teológica Internacional sobre la relación entre Trinidad inmanente y Trinidad económica: "La economía de la salvación manifiesta que el Hijo eterno en su misma vida asume el acontecimiento «kenótico» del nacimiento, de la vida humana y de la muerte en la cruz. Este acontecimiento [...] afecta, de alguna manera, al ser propio de Dios Padre en cuanto que él es el Dios que realiza estos misterios y los vive como propios y suyos con el Hijo y el Espíritu Santo. Pues Dios Padre no solo se nos revela y comunica libre y graciosamente en el misterio de Jesucristo, sino que el Padre con el Hijo y el Espíritu Santo conduce la vida trinitaria de modo profundísimo y —al menos, según nuestra manera de entender - casi nuevo, en cuanto que la relación del Padre al Hijo encarnado en la consumación del don del Espíritu es la misma relación constitutiva de la Trinidad": Comisión Teológica Internacional, Teología-cristología-antropología (1981) I.C,3: <http://www.vatican.va/roman_curia/congregations/cfaith/cti_documents/rc_cti_1982_teologia-cristologia-antropologia_sp.html> [Consulta: 19 mayo 2021]. 
trinitaria acaba teniendo consecuencias para la misma antropología: cuando se habla de "imagen de Dios" sin referencia a Cristo y la encarnación, la dimensión corpórea del ser humano se ve excluida de la teología de la imagen. Las palabras de von Balthasar ("junto al magnífico camino de Agustín, podría haber muchos otros caminos, aún mejores quizá...") conservan todavía plena vigencia y pueden seguir abriéndonos perspectivas. 